\title{
The Influence of Soil Contamination with Diesel Oil on Germination Dynamics and Seedling Development of Selected Species of the Fabaceae family
}

\author{
Bogumiła Pawluśkiewicz' ${ }^{1}$ Tomasz Gnatowski', Maria Janicka² \\ 1 Department of Environmental Improvement, Faculty of Civil and Environmental Engineering, Warsaw \\ University of Life Sciences - SGGW, Nowoursynowska 159, 02-776 Warsaw, Poland \\ 2 Department of Agronomy, Faculty of Agriculture and Biology, Warsaw University of Life Sciences - SGGW, \\ Nowoursynowska 159, 02-776 Warsaw, Poland \\ * Corresponding author's e-mail: maria_janicka@sggw.pl
}

\begin{abstract}
The aim of the study was to determine the effect of soil contamination with diesel oil on the early development of three species of the Fabaceae family (Medicago lupulina L., Lotus corniculatus L., Trifolium repens L.). These species have a wide ecological range and they often occur on extensively used lawns. For these reasons, the knowledge on their tolerance to soil pollution with diesel oil can be of great importance in the creative and conservative cultivation of these plant species and their seed production for establishing the greenery of communication routes. The studies were carried out under controlled laboratory conditions. The soil substrates were composed of the loamy sand mixed with diesel oil in an amount of $2.5 \mathrm{~g}$ and $5.0 \mathrm{~g}$ per $1 \mathrm{~kg}$ of absolute dry mass of soil. The germination dynamics were analyzed. The measurements were conducted twice a day for 12 days after sowing. The development of seedlings was determined on the basis of the length, diameter, area and volume of the radicle. These features were determined on 20-day-old seedlings of the tested species. For the analysis of plant material, the technique of the scanned image was used in the "WinRhizo PRO 2009" software. It was proven that the tested species have various tolerances for the petrol oil in the soil and demonstrate various defense mechanisms under the stress conditions. The least changes of the seed germination rate on the soil with diesel oil against the control were indicated for $L$. corniculatus. The defense strategy of that species relied on the radicle development through increasing the diameter and - in consequence - the surface and the volume. M. lupulina also showed good germination capacity in the presence of diesel oil, but the radicle was shorter in comparison to the control. The germination rate of $T$. repens in the contaminated soil was significantly reduced. The recommendation for using not only L. corniculatus, but also M. lupulina on the contaminated areas should be taken into consideration.
\end{abstract}

Keywords: Fabaceae family, soil pollution, diesel oil, seed germination dynamics, nonlinear function, radicle.

\section{INTRODUCTION}

Nowadays, the contamination of the soil and aquatic environments with oil derivatives is one of the most serious ecological problems. The increase in the consumption of petroleum and its products, due to the decreasing share of coal in energetic balance, causes the escalation of the soil degradation due to the petroleum emissions. According to Panagos et al. [2013], the number of estimated potential contaminated sites in the
European Union is more than 2.5 million, with around 342 thousand identified contaminated sites. Mineral oil and heavy metals are the main contaminants, contributing approx. 60\% to soil contamination. In Poland, the amount of the events with petroleum during only one year reached nearly 3 thousand [Radwan et al. 2012]. The leaks from the pipelines or damaged conveyances and the emission of incomplete fuel combustion are usually the sources of contamination. The diversity of the contamination sources 
causes the petroleum accumulation, including polycyclic aromatic hydrocarbons (PAH), in the soil. Because of difficult biodegradation and toxicity they belong to the persistent and dangerous organic pollutants. They cause cancer of animals and humans, affect soil hydrophobicity and $\mathrm{CO} 2$ emissions, as well as contribute to chlorosis and necrosis of plants [Ziółkowska and Wyszkowski, 2010, Hawrot-Paw et al., 2015, Hewelke et al., 2018]. The ecological policy enforces the Member States of European Union to take the activities focusing on the restoration of the environmental resources. The activities connected with the enlargement of the re-cultivated areas and the development of the methods and reclamation techniques of the polluted areas are the antecedents in the programme of the implementation of that strategy [Report on the implementation of the national ecological policy in the years 2009-2012 with a perspective until 2016. 2014]. On account of the facts that current methods and techniques have not been sufficiently effective and the ecosystems self-purification process is long-lasting, more and more scientific studies consider phytoremediation and phytostabilization [Radziemska et al., 2019]. The relevant problems involve the proper selection of the plants and microorganisms for the peculiar degraded area and maintaining stable turf [Hawrot-Paw and Hreczuk, 2009, dos Santos and Maranho, 2018, Hussain et al., 2018]. In Poland, the grasses, i.e., Dactylis glomerata, Festuca rubra and Lolium perenne, were investigated most often [Małuszyński and Małuszyńska, 2009, Gmitrzuk et al., 2017, Dąbrowski, 2018]. Screening of novel plant species, particularly natives, is recommended with selection focused on species phylogeny, plant morphological and functional traits as well as tolerance towards harsh environmental stresses [Kaur et al., 2017].

The aim of the study was to determine the effect of diesel oil on the early development of three species of the Fabaceae family, i.e., black medick (Medicago lupulina), birdsfoot trefoil (Lotus corniculatus) and white clover (Trifolium repens). These species have a wide ecological range and they often occur on extensively used lawns. For these reasons, the knowledge on their tolerance to soil pollution with diesel oil can be of great importance in the creative and conservative cultivation of these plant species and their seed production for establishing the greenery of communication routes.

\section{MATERIAL AND METHODS}

The studies were carried out under controlled laboratory conditions, in Petri dishes with the diameter of $10 \mathrm{~cm}$, filled with $1 \mathrm{~cm}$ layer of the substrate. The substrate was the topsoil with granulometric composition of weakly loamy sand mixed with diesel oil (DO) in amounts of $2.5 \mathrm{~g}$ and $5.0 \mathrm{~g}$ per $1 \mathrm{~kg}$ of absolute dry matter of soil. The amounts of diesel oil used in the experiments were based on The Regulation of the Minister of Environment concerning soil quality standards and quality standards of soil [2002]. The soil was sterilized prior to contamination.

The control comprised the substrate uncontaminated with diesel oil. The seeds of Medicago lupulina L., Lotus corniculatus L., Trifolium repens L. were sown on April 22, 2015 , in the quantity of 50 per 1 Petri dish, in 5 rows of 10 seeds per row. Three replicates were used for each research variant. The seeds germinated in the light, at a temperature of approx. $24^{\circ} \mathrm{C}$, under constant humidity of the substrate. The germination dynamics and the rate of cotyledons appearance were analyzed. The measurements were conducted twice a day $(8.00 \mathrm{am}$ and $6.00 \mathrm{pm})$ for 12 days after sowing. The results were fitted by the nonlinear function [Scheatzl et al., 1994].

$$
Y(t)=a+b \cdot \exp (-c / t)
$$

where: $Y-$ dependent variable (germination or cotyledons);

$t$ - time (h);

$a+b-$ upper asymptote (count);

$a=0-$ the beginning of the germination or cotyledons experiments;

$c$ - shape parameter (h).

The vigour (first counting $-\mathrm{Fc}$, previously called the energy of germination) and the germination capacity (last counting - Lc) of seeds were determined according to the methodology of the research subject [Dorywalski and Wojciechowicz 1964, ISTA 2015]:

$$
F C(L c)=\frac{N s n}{N c} \cdot 100 \%
$$

where: $N_{s n}$ - the number of the seeds with the radicle not shorter than the caryopsis;

$N_{c}$ - the number of the seeds placed on the Petri dish. 
The energy of germination and the germination capacity of M. lupulina and T. repens were determined after 4 and 7 days respectively, and for L. corniculatus - after 3 and 12 days after sowing.

The development of seedlings was determined on the basis of the length, diameter, area and volume of the radicle. These features were determined on five randomly chosen 20 -day-old seedlings of the tested species. The scanned image technique was used in the "WinRhizo PRO 2009" software for the analysis of plant material.

The results were statistically analyzed by means of the analysis of variance (ANOVA) in the Statgraph PRO software [STSC 1996]. The significance of the differences was verified with the help of the Tuckey test with the significance level $\alpha=0.05$

\section{THE RESULTS AND DISCUSSION}

\section{The germination progress}

The used nonlinear function (1) describes the legume germination process of plants very well. The compatibility of the measurements with mathematic function exceeds $95 \%$ in average (Table 1). The investigated species vary in the germination rate and the time of cotyledons appearance as well as the reaction on the diesel oil content in the soil during their development (Table 1, Figure 1).

Medicago lupulina had with the quickest germination rate under control conditions. On the soil with no diesel oil (0DO) the germination rate was most intensive till 65 hours (the point of the germination rate curve inflection - parameter $c$ ).
The number of germinated seeds 65 hours after seeding was equal to 21 (42 percent of all the sown seeds in the dish). Under the conditions of $2.5 \mathrm{~g}$ diesel oil content in the soil (1DO) such share of germinated seeds occurred not until 95 hours, i.e. more than 24 hours later. The germination rate on the soil with $5 \mathrm{~g}$ of diesel oil (2DO) was even smaller. Forty percent share was obtained not until 133 hours, e.g. twice later than in control and 38 hours later than on the soil with $2.5 \mathrm{~g}$ of diesel oil (1DO). The germination rate in the following hours (from the point of inflection to maximal value) on the soil with diesel oil was smallest on the soil 1DO (11\% smaller than in control and $8 \%$ smaller than on 2DO). Finally, after 288 hours ( 12 complete periods of 24 hours) the number of seeds germinated on the soil with diesel oil regardless of its amount (1DO, 2DO) was similar and smaller in the comparison with the control of $16.2 \%$ in average (0DO).

The characteristics of seeds germination under the control conditions (0DO) and on the soils with diesel oil (1DO, 2DO) were different for Medicago lupulina in comparison to Lotus corniculatus. Lotus corniculatus germinated much slower and the rate of that process on the soils with diesel oil was more dependent on its content in the soil than in the case of M. lupulina. The points of inflection $(c)$ of the germination rate curve for L. corniculatus on the soil without oil (DO0) and with $2.5 \mathrm{~g}$ of oil (1DO) were obtained after similar time. The process of germination of that seeds was rectilinear till 132.5 hours in average. Till that time $40 \%$ of the seeds germinated on the soil without oil and $35 \%$ - with $2.5 \mathrm{~g}$ of oil (1DO). Those shares of germinated seeds were obtained 2 and 1.4 times later, respectively, than

Table 1. The parameters of nonlinear function (1) describing process of germination and cotyledons appearance for investigated legume species. The values of the coefficient describing the logistic curve parameters in the process of germination and cotyledons appearance for legume species

\begin{tabular}{|c|c|c|c|c|c|c|c|c|c|}
\hline \multirow{3}{*}{$\begin{array}{l}\text { Species } \\
\text { Co-efficient }\end{array}$} & \multicolumn{3}{|c|}{ Medicago Iupulina } & \multicolumn{3}{|c|}{ Lotus corniculatus } & \multicolumn{3}{|c|}{ Trifolium repens } \\
\hline & \multicolumn{9}{|c|}{ The level of diesel oil contamination ( $\mathrm{g} \mathrm{kg}^{-1}$ soil d.m.) } \\
\hline & $\begin{array}{c}0 \\
(0 D O)\end{array}$ & $\begin{array}{c}2.5 \\
(1 \mathrm{DO}) \\
\end{array}$ & $\begin{array}{c}5.0 \\
(2 \mathrm{DO}) \\
\end{array}$ & $\begin{array}{c}0 \\
(0 D O)\end{array}$ & $\begin{array}{c}2.5 \\
(1 \mathrm{DO}) \\
\end{array}$ & $\begin{array}{c}5.0 \\
(2 \mathrm{DO})\end{array}$ & $\begin{array}{c}0 \\
(0 D O) \\
\end{array}$ & $\begin{array}{c}2.5 \\
(1 \mathrm{DO}) \\
\end{array}$ & $\begin{array}{c}5.0 \\
(2 \mathrm{DO})\end{array}$ \\
\hline \multicolumn{10}{|c|}{ The germination rate } \\
\hline $\mathrm{b}(-)$ & 57.99 & 54.64 & 60.91 & 53.98 & 47.89 & 55.88 & 51.77 & 39.09 & 39.10 \\
\hline $\mathrm{c}(\mathrm{h})$ & 65.43 & 95.01 & 133.46 & 133.60 & 131.36 & 196.25 & 137.92 & 140.54 & 168.86 \\
\hline $\mathrm{R}^{2}(\%)$ & 99.20 & 98.76 & 98.77 & 94.69 & 91.92 & 94.31 & 98.86 & 98.79 & 99.10 \\
\hline \multicolumn{10}{|c|}{ The rate of cotyledons appearance } \\
\hline $\mathrm{b}(-)$ & 274.23 & 283.98 & 179.12 & 52.16 & 80.09 & 57.56 & 48.01 & 59.37 & 64.67 \\
\hline$c(h)$ & 654.75 & 702.34 & 606.63 & 303.82 & 544.85 & 442.89 & 276.83 & 367.40 & 425.08 \\
\hline $\mathrm{R}^{2}(\%)$ & 97.84 & 98.90 & 98.56 & 97.43 & 98.35 & 98.92 & 99.14 & 99.07 & 98.61 \\
\hline
\end{tabular}


a)

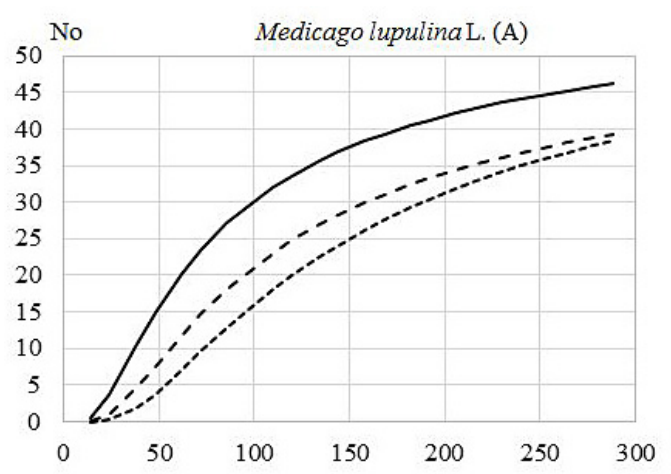

(h)

c)

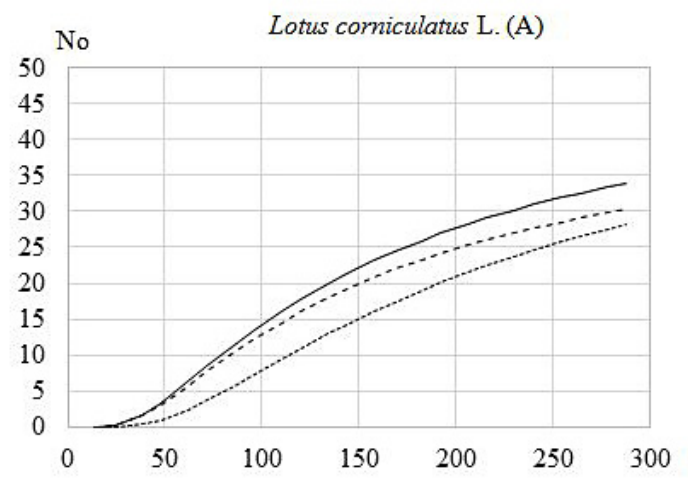

(h)

e)

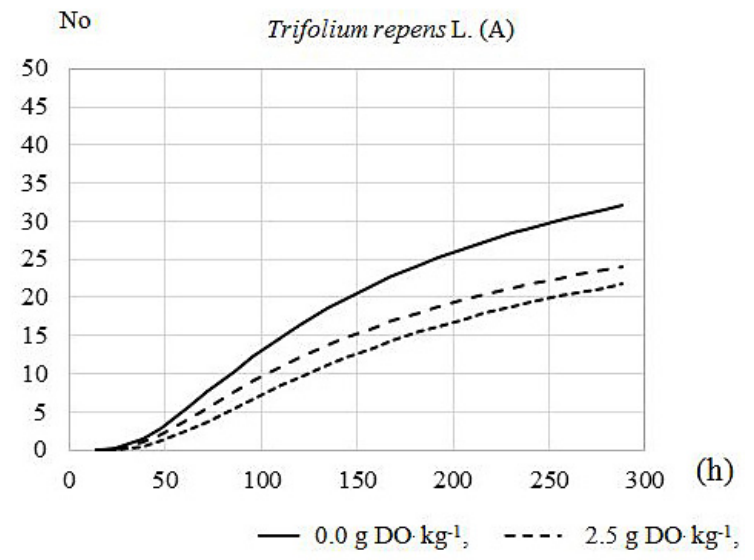

b)

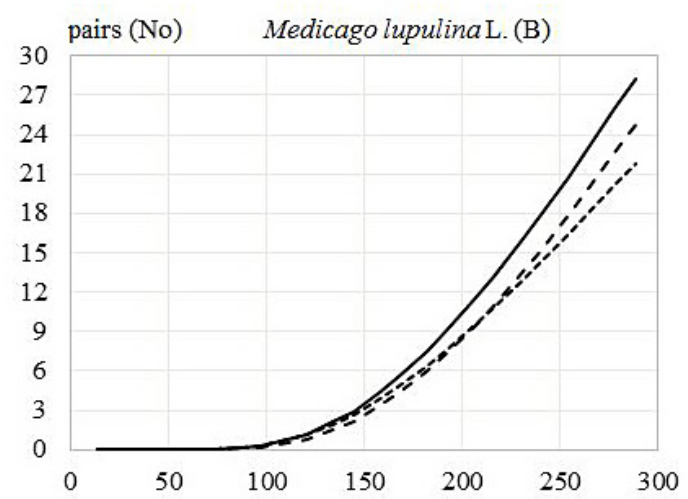

(h)

d)

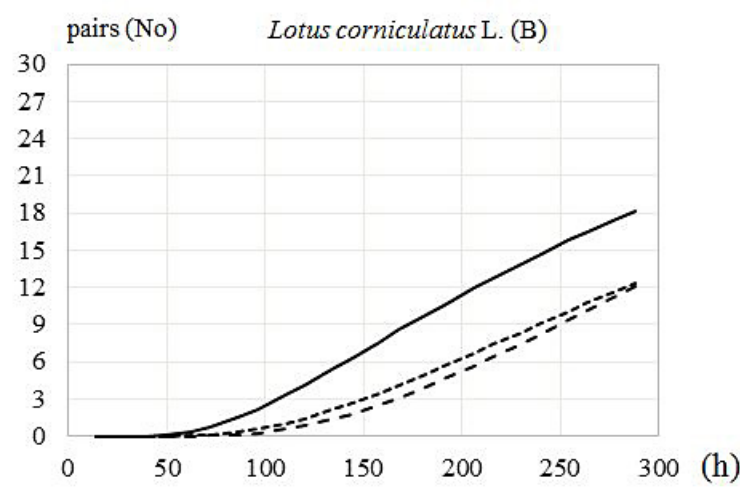

f)

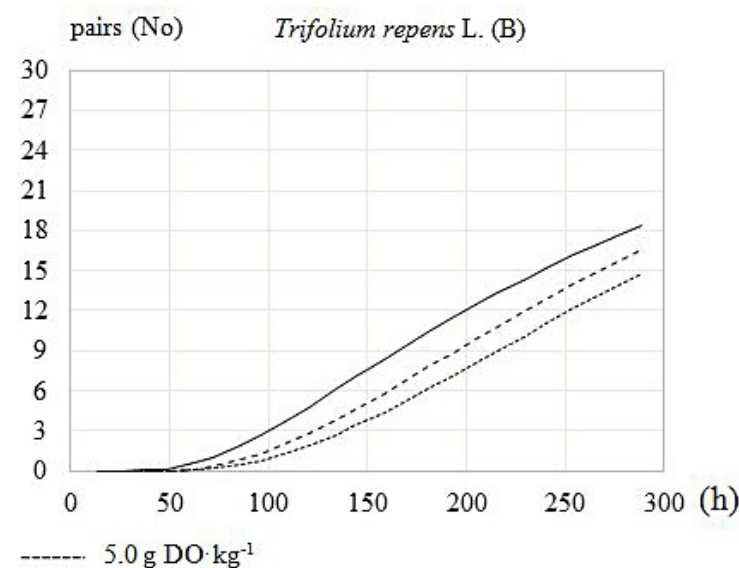

Figure 1. The seeds germination rate (A) and cotyledons appearance (B) depending on the contents of the diesel oil in the soil (DO)

in the case of M. lupulina. The rate of L. corniculatus germination, for the seeds sown on the soil with $5 \mathrm{~g}$ of oil (2DO) was 1.5 -times slower than on control and on the soil with half the contamination value. The period of 196 hours, e.g. 64 hours more than on other soils, was necessary for obtaining the $40 \%$ shares of the germinated seeds number. The value of $b$ parameter of the curve shows that in the following hours (from the point of inflection $(c)$ ) the process of seed germination run slowest on the soil with $2.5 \mathrm{~g}$ of oil (1DO), as in the case of M. lupulina. It was $11 \%$ smaller in the comparison with the control and 3\% smaller against the 2DO soil. After 288 hours, the number of germinated L. corniculatus seeds on the soil with $2.5 \mathrm{~g}$ and $5 \mathrm{~g}$ of diesel oil was $10.6 \%$ and $16.7 \%$ smaller in the comparison with the control, respectively.

The rate of Trifolium repens seeds germination was smallest and the differences between the 
control and the soil with petrol oil - larger than for the rest of the legume plant species. Although the inflection points $(c)$ on the control (0DO) and on the soil with $2.5 \mathrm{~g}$ of diesel oil (1DO) were obtained after a similar period (138 and 140 hours), the number of germinated seeds on the soil with oil (1DO) was $24.5 \%$ lower against the control and equal to $28 \%$ of all sown seeds. On the soil with twice higher content of diesel oil (2DO) the value of $28 \%$ of germinated seeds was obtained 28 hours later. In the following hours till 12 day after sowing, the rate of the seeds germination on the control was also significantly higher, $27 \%$ in average, against the soils with petrol oil. As the result of such germination process after 288 hours, the difference in the number of germinated seeds on the control and on the soil with $2.5 \mathrm{~g}$ of oil was equal to $25.5 \%$ and $32.2 \%$ on the soil with $5 \mathrm{~g}$ of oil.

\section{The energy and germination capacity}

Various germination courses of three legume plant species are shown by the values of the energy and seed germination capacity. The germination energy is the parameter demonstrating the rate of the uptake and important for the area managing. The quick uptake mean the larger competitiveness of the sown species against the germinating seeds from the soil seed bank and better final effect of the forming biologically active areas [Pawluśkiewicz et al., 2019]. Under the control conditions the seeds of Medicago lupulina showed decidedly highest germination energy (Table 2). Its value was - in average - three times higher than of other species. Significantly lesser value of seeds germination energy was characterised for Trifolium repens. Only 20\% of the seeds germinated in short time, taken for that species. The value of the germination energy for Lotus corniculatus was also low (26\%), but significantly higher than for T. repens. The species differences could be the result of higher number so-called hard seeds of $T$. repens.

The significant intra-species differences were also noted on the soils with the diesel oil. The reactions for the soil contamination were similar in the cases of $L$. corniculatus and T. repens. No significant differences of the germination energy were observed on the control and on the soil with $2.5 \mathrm{~g}$ of diesel oil (1DO). Significant differences were indicated just on the soil with its twice higher content (2DO). The values of the germination energy of $L$. corniculatus and $T$. repens were 1.5 times higher in average and equal to $18 \%$ and $12 \%$, respectively. The M. lupulina was characterised by higher sensitivity to the diesel oil in the soil than the species mentioned above. Significantly lower value of the germination energy (of $33 \%$ ) was already found on the soil with $2.5 \mathrm{~g}$ of oil (1DO). Twice higher amount of that substance in the soil did not cause further differences. The germination energy value in that case was equal to $34 \%$ and was 1.8 times lower than in control.

The germination capacity is the parameter indicating the vitality of seeds. Under the control conditions, Medicago lupulina and Lotus corniculatus had with similar (statistically insignificant), high (79\% in average) value of the germination capacity (Table 2). The germination capacity of Trifolium repens was significantly lower, which may confirm the assumption about the high number of the hard seeds, requiring scarification before sowing. The soil contamination with $2.5 \mathrm{~g}$ (1DO) of diesel oil caused a significant decreasing

Table 2. The energy and germination capacity of three legume species depending on the diesel oil content in the soil (DO)

\begin{tabular}{|c|c|c|c|}
\hline \multirow{2}{*}{ Species } & \multicolumn{3}{|c|}{ The level of contamination $\left(\mathrm{g} \mathrm{kg}^{-1} \mathrm{DM}\right.$ of the soil) } \\
\hline & $0(\mathrm{ODO})$ & 2.5 (1DO) & $5.0(2 \mathrm{DO})$ \\
\hline & \multicolumn{3}{|l|}{ The germination energy $(\%)$} \\
\hline Medicago lupulina L. & $60^{\mathrm{aA}}$ & $40^{\mathrm{bA}}$ & $34^{\mathrm{bA}}$ \\
\hline Lotus corniculatus L. & $26^{\mathrm{aB}}$ & $26^{\mathrm{aB}}$ & $18^{\mathrm{bB}}$ \\
\hline Trifolium repens $\mathrm{L}$. & $20^{\mathrm{aC}}$ & $18^{\mathrm{ac}}$ & $12^{\mathrm{bC}}$ \\
\hline \multirow[t]{2}{*}{ Mean } & $35.3^{a}$ & $28.0^{\mathrm{b}}$ & $21.3^{c}$ \\
\hline & \multicolumn{3}{|l|}{ The germination capacity (\%) } \\
\hline Medicago lupulina L. & $82^{\mathrm{aA}}$ & $62^{\mathrm{bA}}$ & $52^{\mathrm{cA}}$ \\
\hline Lotus corniculatus L. & $76^{\mathrm{aA}}$ & $68^{\mathrm{bA}}$ & $60^{\mathrm{cA}}$ \\
\hline Trifolium repens $\mathrm{L}$. & $46^{\mathrm{aB}}$ & $34^{\mathrm{bB}}$ & $30^{\mathrm{bB}}$ \\
\hline Mean & $68.0^{\mathrm{a}}$ & $54.7^{\mathrm{b}}$ & $47.3^{c}$ \\
\hline
\end{tabular}

Note: ${ }^{\text {a-c }}$ homogenous groups in the rows, ${ }^{\mathrm{A}-\mathrm{C}}$ homogenous groups in the columns. 
in the germination capacity for all studied species, $20 \%$ in average. The L. corniculatus had the lowest difference between the values of the germination capacity obtained on the control and on the soil with that content of diesel oil (1DO). Twice higher content of the diesel oil in the soil (2DO) caused a significant decrease in the germination capacity of two species, i.e. M. lupulina and $L$. corniculatus. Nevertheless the mentioned values were relatively high and equal to $52 \%$ and $60 \%$, respectively. The T. repens germination capacity was almost half of these values and equal to $30 \%$.

\section{The rate of the cotyledons appearance}

The parameters of the nonlinear function presenting the rate of the legume plants' cotyledons appearance indicate that the point of inflection (c) and the upper asymptote $(b)$ are located outside the area shown in Figure 1. It means that over 288 hours (i.e. the investigation period) the intensive increasing in the number of occurring cotyledons took place. The used function presents the plant development feature very well (avg. $\mathrm{R}^{2}=98.5 \%$ ). The interpretation of the characteristic parameters of that function is not fully possible (the point of inflection outside the measurement range). On the other hand, owing to a detailed analysis of that part of the linear path, it was possible to determine more precisely-for all the species - the time necessary for the appearance of cotyledons and the influence of petrol oil on that process. Moreover, the use of the same function as in the description of the seeds germination allows for the connection of those two development processes.

It was proven that the species differed in the time of first appearance of cotyledons and the rate of their occurrence in the following hours. Amongst the studied species, Medicago lupulina showed the latest appearance of the cotyledons. They appeared only 96 hours after sowing, independently to the amounts of the diesel oil in the soil and the number of germinated seeds. Despite the late appearance of the cotyledons in the following hours, a high increase in the number of plants with cotyledons outside the seed coats took place. On all the soils (0DO, 1DO, 2DO) the rate of that process was significantly higher than in the cases of other species. Finally, after 288 hours, $56 \%$ of the plants on the soil with no diesel oil had the cotyledons, on the soil with $2.5 \mathrm{~g}$ of oil (1DO) $-50 \%$ and $44 \%$ on the soil with $5 \mathrm{~g}$ of oil (2DO). In the cases of Lotus corniculatus and
Trifolium repens the appearance of the cotyledons on the control soil was very similar. The first ones appeared after 62 hours and after 288 hours the number of the plants with cotyledons was equal to 18 ( $37 \%$ of sown ones). The mentioned species varied in the sensitivity for the diesel oil presence in the soil. The L. corniculatus showed a significantly slower rate of the cotyledons appearance on the soils with oil, independently of its amount. They appeared 34 hours later and their amount was of $32 \%$ lesser than on control. The obtained results also show that the defence mechanism of that species under stress conditions provoked by the oil presence relies on the quick development of the radicle and the limitation of the aboveground parts development. Another mechanism was shown by $T$. repens. On the soils with oil, the cotyledons appeared at a similar rate than the radicle. The rate of the cotyledons appearance was similar to the one on the control. The first cotyledons appeared 39 hours later and the difference in the number of the plants with the cotyledons after 288 hours was equal to $9.8 \%$ on the soil with $2.5 \mathrm{~g}$ of oil (1DO) and $19.6 \%$ on the soil with $5 \mathrm{~g}$ of oil (2DO) in the comparison with the control.

\section{The radicle morphology}

The values of the length, width, surface and volume of the radicle were shown in Table 3. It was stated that Medicago lupulina - in the comparison with Lotus corniculatus and Trifolium repens - showed significantly higher values of the investigated parameters, but only on the soil with no diesel (0DO). No significant differences between the species were noted on the soils with diesel oil (1DO, 2DO), but the presence of that substance significantly influenced the change in the radicle dimensions of studied legume plants. A significant impact from the change in root morphology as a reaction to the diesel oil showed also Zhan et al. [2013], Małachowska-Jutsz [2012] and Tran et al. [2018]. The reaction was specific for particular species. Under the influence of the diesel oil, independently to its amount in the soil, M. lupulina formed significantly (of $31 \%$ ) radicle, of slightly larger diameter (of 10\%) than on control. Finally, the radicle surfaces on the soils with oil (1DO, 2DO) were smaller (of 16\%) than on the soil with no oil, but the differences were not proven statistically. The volume of that species' radicle was the same on all the soils. 
Table 3. The parameter values characterizing the radicles of three legume species in dependency on the diesel oil content in the soil (DO)

\begin{tabular}{|c|c|c|c|}
\hline \multirow{2}{*}{ Species } & \multicolumn{3}{|c|}{ The level of contamination ( $\mathrm{g} \mathrm{kg}^{-1} \mathrm{DM}$ of the soil) } \\
\hline & 0 (ODO) & 2.5 (1DO) & $5.0(2 \mathrm{DO})$ \\
\hline & \multicolumn{3}{|l|}{ Lenght $(\mathrm{cm})$} \\
\hline Medicago Iupulina L. & $7.04^{\mathrm{aA}}$ & $4.86^{\mathrm{bA}}$ & $4.86^{\mathrm{bA}}$ \\
\hline Lotus corniculatus L. & $3.89^{\mathrm{aB}}$ & $4.00^{\mathrm{aA}}$ & $3.99^{\mathrm{aA}}$ \\
\hline Trifolium repens L. & $3.47^{\mathrm{aB}}$ & $5.05^{\mathrm{bA}}$ & $4.56^{\mathrm{abA}}$ \\
\hline \multirow[t]{2}{*}{ Mean } & $4.80^{a}$ & $4.63^{a}$ & $4.47^{a}$ \\
\hline & \multicolumn{3}{|l|}{ Diameter $(\mathrm{cm})$} \\
\hline Medicago Iupulina L. & $0.257^{\mathrm{aA}}$ & $0.283^{\mathrm{aA}}$ & $0.283^{\mathrm{aA}}$ \\
\hline Lotus corniculatus L. & $0.200^{\mathrm{aB}}$ & $0.355^{\mathrm{bA}}$ & $0.304^{\mathrm{bA}}$ \\
\hline Trifolium repens $\mathrm{L}$. & $0.207^{\mathrm{aB}}$ & $0.276^{\mathrm{bA}}$ & $0.269^{\mathrm{abA}}$ \\
\hline \multirow[t]{2}{*}{ Mean } & $0.221^{\mathrm{a}}$ & $0.305^{b}$ & $0.285^{\mathrm{bA}}$ \\
\hline & \multicolumn{3}{|l|}{ Area $\left(\mathrm{cm}^{2}\right)$} \\
\hline Medicago lupulina L. & $0.578^{\mathrm{aA}}$ & $0.484^{\mathrm{aA}}$ & $0.484^{\mathrm{aA}}$ \\
\hline Lotus corniculatus L. & $0.244^{\mathrm{aB}}$ & $0.437^{\mathrm{bA}}$ & $0.380^{\mathrm{abA}}$ \\
\hline Trifolium repens L. & $0.217^{\mathrm{aB}}$ & $0.487^{\mathrm{bA}}$ & $0.404^{\mathrm{bA}}$ \\
\hline \multirow[t]{2}{*}{ Mean } & $0.346^{a}$ & $0.469^{b}$ & $0.423^{\mathrm{ab}}$ \\
\hline & \multicolumn{3}{|l|}{ Volume $\left(\mathrm{cm}^{3}\right)$} \\
\hline Medicago lupulina L. & $0.004^{\mathrm{aA}}$ & $0.004^{\mathrm{aA}}$ & $0.004^{\mathrm{aA}}$ \\
\hline Lotus corniculatus L. & $0.001^{\mathrm{aB}}$ & $0.004^{\mathrm{bA}}$ & $0.003^{\mathrm{bA}}$ \\
\hline Trifolium repens L. & $0.001^{\mathrm{aB}}$ & $0.004^{\mathrm{bA}}$ & $0.003^{\mathrm{abA}}$ \\
\hline Mean & $0.002^{\mathrm{a}}$ & $0.004^{b}$ & $0.003^{b}$ \\
\hline
\end{tabular}

Note: ${ }^{\text {a-c }}$ homogenous groups in the rows, ${ }^{\text {A-C }}$ homogenous groups in the columns.

Different reaction on the diesel oil presence in the soil was shown by L. corniculatus. The radicle diameter was significantly larger (of $77.5 \%$ on $1 \mathrm{DO}$ and of $52 \%$ on 2DO) and its length only slightly greater (of $2.6 \%$ ) than on control. Finally, the surface and volume of the radicle were significantly larger on the soil with oil than without one. On the soil with $2.5 \mathrm{~g}$ of that substance (1DO), the radicle surface was almost two times larger, and the volume - three times greater than on control. Two times higher amount of petrol oil in the soil (2DO) also caused twofold larger volume and $56 \%$ greater surface of the radicle in the comparison with the development on the control base.

The $T$. repens showed higher all the radicle parameters on the soils contaminated with diesel oil than on control. The greatest, significant differences of the radicle development occurred on the soil with $2.5 \mathrm{~g}$ of diesel oil (1DO). The lengths and widths of the radicles were $45.5 \%$ and $33.3 \%$ greater than on the soil without oil, respectively. It was reflected in 2.2-times larger surface and three times larger volume of the radicle. On the soil with $5 \mathrm{~g}$ of diesel oil longer (of 33\%) and wider (of $29.9 \%$ ) radicle were obtained, but the values significantly higher than on control were not observed. However, the significant difference was proven for the surface of that species radicle.

\section{CONCLUSIONS}

The soil contamination with the petrol oil significantly impacted the preliminary growth of the legume plants (Medicago lupulina, Lotus corniculatus, Trifolium repens) and the radicle morphology. Independently of the species, the germination rate (appearance of the root and the cotyledons) was significantly lesser than under the control conditions (adequately to the diesel oil amount in the soil). The Schatzel logistic curve well describes the development process of the studied species after the sowing and enables the demonstration of the differences in its rate, better than the often applied parameters (the energy of the germination and its capacity). The relevance of germination studies as important ecotoxicological tools is highlighted with root imaging software. It was proven that peculiar species have various tolerances for the petrol oil presence in the soil and demonstrate various defence mechanisms under the stress conditions. The least changes in germination rate of seeds on the soil with petrol oil against the control were stated for L. corniculatus. The defence strategy of that species relied on the radicle development through the increasing in diameter and - in consequence - the surface and the volume. The soil contamination 
with diesel oil affected mostly the decrease in the rate of Trifolium repens germination. The species reacted on the stress conditions by quick appearance of cotyledons as well as the growth and increase in the diameter of the radicle, especially on the soil with smaller content of diesel oil $(2.5 \mathrm{~g})$. Two times higher content of that substance significantly limited the radicle development. According to Małachowska-Jutsz et al. [2012], extension of the cells in order to increase the radicle surface and develop new root hairs, is the plants defence mechanism, because the oil causes the clogging of the vascular cells, used for water intake. Amongst the studied species, M. lupulina showed the best germination capacity in the presence of diesel oil, but the differences in that parameter value and the radicle morphology against the control were large (equal to $31 \%$ - lesser germination capacity and shorter radicle). It seems that good (above $50 \%$ ) germination capacity of that species may be the result of larger size of seeds in the comparison with $T$. repens. The results of other authors proved that such species show better emergences [Hitchmough, 2017, Janicka et al., 2019]. Because of that, the recommendation for using not only $L$. corniculatus, but also M. lupulina on the contaminated areas should be taken into consideration. These species could be especially valuable for the re-cultivation of the soils contaminated with petroleum products, which would make the quicker phytoremediation successes possible. As indicated by the own and other authors' research [Zhan et al. 2013], further work is necessary to determine the equation of the predictive effect by morphology and physiology of plant root on the soils contaminated with petroleum substances.

\section{REFERENCES}

1. Dąbrowski P. 2018. The ecophysiological reactions of Lolium perenne L. and Festuca rubra ssp. commutata on chosen stress factors in aspect of the green urban infrastructure's improvement. Wydawnictwo SGGW, Warszawa. 1-138. [In Polish]

2. Dorywalski J., Wojciechowicz M. 1964. Seed assessment methodology. PWRiL, Warszawa. [In Polish]

3. Gmitrzuk N., Dąbrowski P., Pietrzyk K. and Pawluśkiewicz B. 2017. The impact of diesel and naphthalene on the initial growth and development of red fescue (Festuca rubra L. ssp. commutata). Scientific Review. Engineering and Environmental Sciences 26/3 (77), 361-372. [In Polish]
4. Hawrot-Paw M., Hreczuk H. 2009. Potential remediation property of chosen plants species. Proc. of the Conference Materials 'Degraded and reclaimed areas - the possibility of their development', Szczecin, 65-70. [In Polish]

5. Hawrot-Paw M., Wijatkowski A., Mikiciuk M. 2015. Influence of diesel and biodiesel fuel-contaminated soil on microorganisms, growth and development of plants. Plant Soil Environ. 61(5), 189-194.

6. Hewelke E., Szatyłowicz J., Hewelke P., Gnatowski T., Aghalarov R. 2018. The impact of diesel oil pollution on the hydrophobicity and $\mathrm{CO}_{2}$ efflux of forest soils. Water Air Soil Pollut. 229:51.https://doi. org/10.1007/s11270-018-3720-6

7. Hitchmough J. 2017. Sowing beauty. Designing flowering meadows from seed. Timber Press Portland. Oregon.

8. Hussain I., Puschenreiter M., Gerhard S., Schöftner Ph., Yousafd S., Wang A., Syed J.H., Reichenauer T.G. 2018. Rhizoremediation of petroleum hydrocarbon-contaminated soils: Improvement opportunities and field applications. Environmental and Experimental Botany 147, 202-219.

9. ISTA 2015. International Seed Testing Association. International Rules for Seed Testing. IHAR-PIB ZNiN,1-766. [In Polish]

10. Janicka M., Pawluśkiewicz B., Małuszyńska E. 2019. The analysis of the traits determining the development of some plant species typical for the meadow habitats of the Natura 2000 network. Scientific Review - Engineering and Environmental Sciences 28(1), 82-94.

11. Kaur N., Erickson T. E., Andrew S. B., Ryan M. H. 2017. A review of germination and early growth as a proxy for plant fitness under petrogenic contamination - knowledge gaps and recommendations, Science of the Total Environment 603-604,728-744.

12. Małachowska-Jutsz A. Janosz W., Rudek J. 2012. Toxicity of Engine Oil Contaminated Soil Made Subject to Natural Attenuation and Phytoremediation. Ochrona Środowiska 34(1), 15-20. (In Polish)

13. Małuszyński M. J., Małuszyńska I. 2009. Immunity of selected plants species on soil pollution of overworked engine oil. Inżynieria Ekologiczna 21, 40-47. [In Polish]

14. Panagos P., Van Liedekerk M., Yigini Y., Montanarella, L. 2013. Contaminated sites in Europe: review of the current situation based on data collected through a European network. Journal of Environmental and Public Health, Article ID 158764. https://doi.org/10.1155/2013/158764.

15. Pawluśkiewicz B., Janicka M., Piekut K. 2019. Effects of different introduction methods on plant species establishment success in wet grassland restoration. Polish Journal of Environmental Studies 28(3), 1857-1867. 
16. Radziemska M., Bęś A., Gusiatin Z.M., Cerdà A., Mazur Z., Jeznach J., Kowal P., Brtnický M. 2019. The combined effect of phytostabilization and different amendments on remediation of soils from post-military areas. Science of the Total Environment 688, 37-45.

17. Radwan K., Ślosarz Z., Rakowska J. 2012. Environmental effects of oil pollutants. Technika i Technologia 3, 107-114. [In Polish]

18. Regulation of the Minister of Environment on soil quality standards and soil quality standards earth. 2002. Dz.U. 165 poz. 1359). [In Polish]

19. Report on the implementation of the national ecological policy in the years 2009 - 2012 with a perspective until 2016. 2014. Printing Commission of the Council of Ministers. DKRM-4822-7(8)14. 2691, 272. [In Polish]

20. dos Santos J.J., Maranho L.T. 2018. Rhizospheric microorganisms as a solution for the recovery of soils contaminated by petroleum: A review. Journal of Environmental Management 210, 104-113.
21. Schaetzl R.J., Barett L.R., Winkler J.A. 1994. Choosing models of soil chronofunctions and fitting them to data. Europen Journal of Soil Sci. 45, 219-232.

22. STSC-Inc.-Statistical Graphics Corporation. 1996. STATGRAPHICS Plus - Statistical Graphics System - ver. 2.1. Rockvile. Maryland, USA.

23. Tran T.H., Gati E.M., Eshel A., Winters G. 2018: Germination, physiological and biochemical responses of acacia seedlings (Acacia raddiana and Acacia tortilis) to petroleum contaminated soils Environmental Pollution 234, 642-655.

24. Zhan X., Liang X., Xu G., Zhou L. 2013: Influence of plant root morphology and tissue composition on phenanthrene uptake: Stepwise multiple linear regression analysis. Environmental Pollution 179, 294-300.

25. Ziółkowska A., Wyszkowski M. 2010. Toxicity of petroleum substances to microorganisms and plants. Ecological Chemistry and Engineering 17, 73-82. 